منهج الإمام الماوردى - رحمه الله - فى النقد

$$
\begin{aligned}
& \text { منهج الإمام الماوردى - رحمه الله - فى النقد } \\
& \text { الباحث/ محمد حسن محمد }
\end{aligned}
$$

لارجة الكتوراة -كلية التربية - قسم أصول التربية الإسلامية

\title{
جامعة الزقازيق
}

مقدمة :

الحمد لله رب العالمين والصـلاة والسـلام على الرسـول الأمين وعلى الـه وأصـحابه

$$
\text { ومن اتبعهم بإحسان إلى يوم الدين وبعد : }
$$

كان للعلماء المسلمين جهوداً نقدية لتقويم العلوم والمعارف ولبيان الحق من الباطل

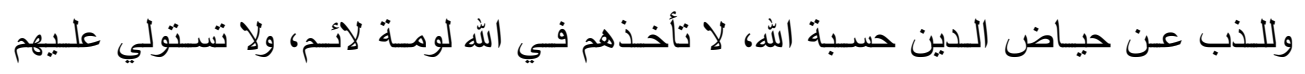

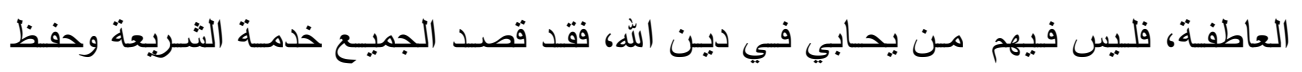

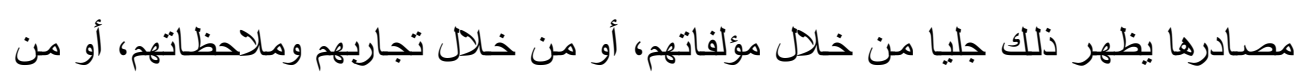

وفي هذا البحث نعرض شيئا من منهج الإمام أبو الحسن علي بن محمد بن حبيب

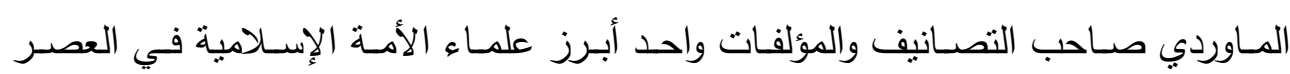
العباسي.

وقد اجتهدت في تقسيم البحث إلى المباحث التالية :

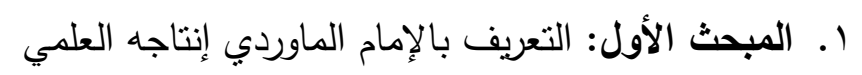

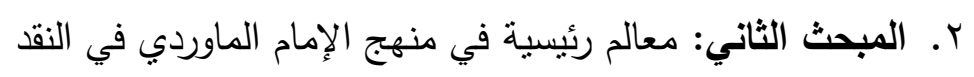
r. المبحث الثالث: أسباب وأهداف النقد عن الإمام الماوردي. مئم فئي. ع. المبحث الرابع: أخلاقيات وضوابط النقد عند الإمام الماوردي.

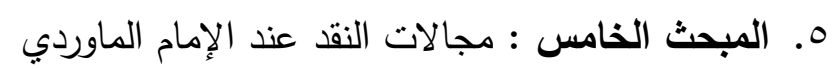

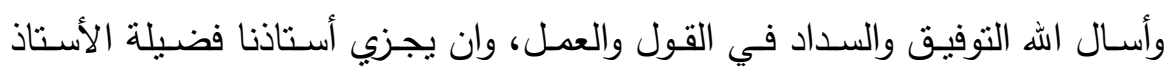
الدكتور عبد الرحمن الأنصاري خير الجزاء على ما قدم لنا وأفادنا خـلاد تدربسه لنا في هذا

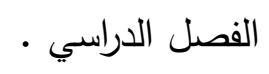


المبحث الأول : التعريف بالإمام الماوردي إنتاجه العلمي

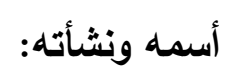

أبو الحسن علي بن محمد بن حبيب الماوردي، ولد بالبصرة عام ع ؟ب هـ/ع عوم،

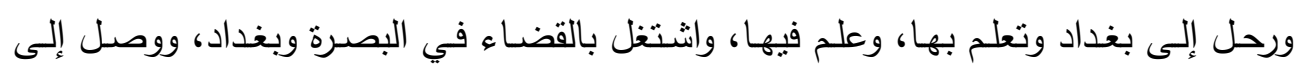

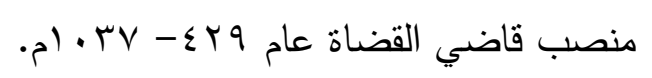

واشتهر الماوردي في الفكر الإسـلامي ببحوثه السياسية، وتكاد أن تكون تلك هي

صبغته، فكتب كتابه الهام الذي ارتبط باسمه فيقال صاحب كتاب: "الأحكام السلطانية"، كما ولإن

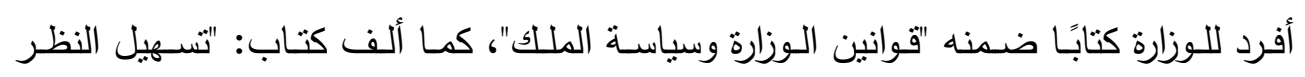
وتعجيل الظفر" وهو أيضًا في السياسة.

وقد ساعد الماوردي في كتاباته السياسية قربه من الخلفاء والملوك والوزراء وعمل يله

سفيرًا بينهم وبين خصومهم السياسبين.

وكان المـاوردي أديبًا لغويًا، أثرى الأدب العربي، كما كتب في الأخـاق والتربية،

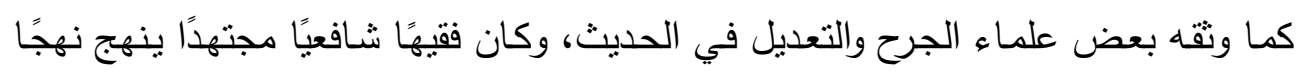
علميًا يكاد يكون حديثًا، فيعرض لوجهات النظر المتعارضـة والمختلفة في المسألة الواحدة ويرجح بينها، وينتهي لرأي، يرى فيه وجه الحق والصواب حتى انتهت إليه زعامة الثـافعية في عصره.

وانفرد في تفسيره ببعض الاتجاهـات التي تدل على أصسالة وعمق في التفكير،

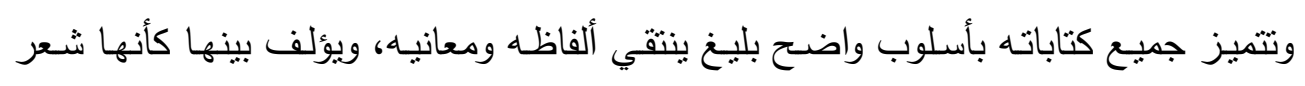
منثور

وكان أخلاقيًا في سبرته ومعاملاته بين الناس، وعمر طويلًا فعاش ستًا وثمانين

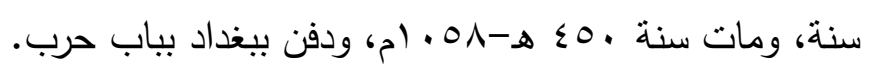
شيوخه:

تتلمذ الماوردي على يا شيخين كبيرين:

أحدهما: أبو القاسم عبد الواحد بن الحسين الصيمري، ولم نجد شينًا كثيرًا عنه في كتب التراجم وكل ما وصلنا إليه أنه سكن البصرة وارتحل إليه الناس من أماكن كثيرة، وكان

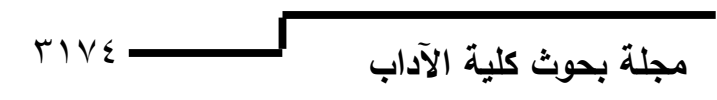


منهج الإمام الماوردى - رحمه الله - فى النقد

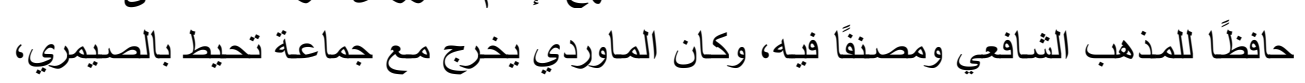

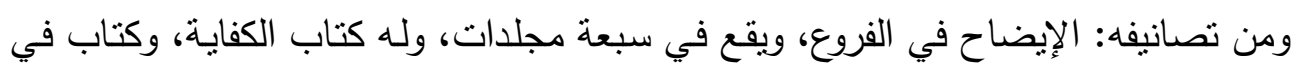

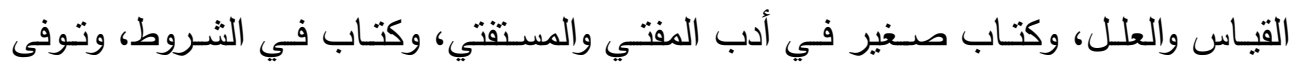
الصيمري بعد عام • ^ب هـ، وقد وضحت آثار هذه الكتب في مؤلفات واتجاهات الماوردي. الثاني: الثيخ أبو حامد بن محمد بن أحمد الإسفراييني: انتهت إليه رئاسة الدين والدنيا في بغداد، وكان يتميز بالثجاعة في إبداء الرأي وما

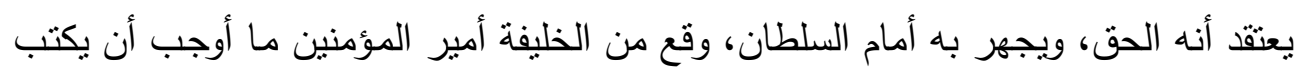

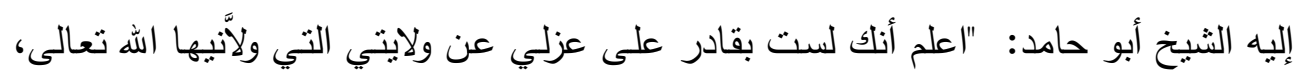
وأنا أقدر أن أكتب رقعة إلى خراسان بكلمنين أو ثلات أعزللك عن خلافتك"، هذه دلالة على ولى التى ما كان يتمتع به الإسفراييني من الثجاعة وقوة التأثثر وكثرة الأتباع.

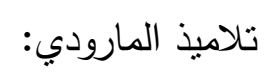

تخرج على الماوردي جماعة من التلاميذ برز منهم: الخطيب البغدادي، أبو بكر

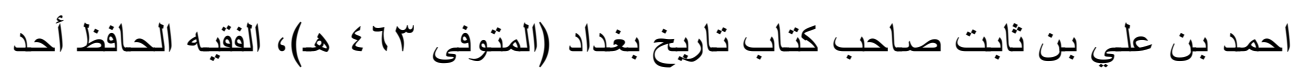

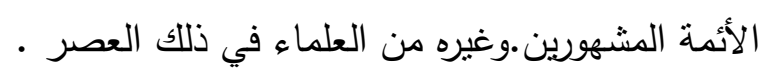

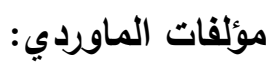

ألف الماوردي كتابًا في تفسير القرآن الكريم اسماه "النكت والعيون في تأويل القرآن

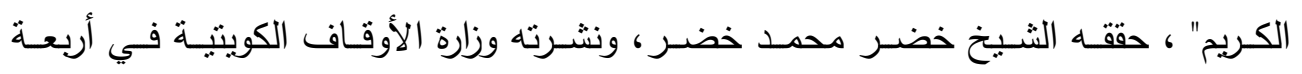
مجلدات. كتاب الحاوي الكبير وكتاب الإقناع: قال المـارودي : "بسطت الفقه في أربعة آلاف ورقـة واختصـرته في أربعين" يريد بالمبسوط كتاب الحاوي، وبالمختصر كتاب الإقناع وكتاب "الحـاوي الكبير" موسـوعة فقهيـة، وكتـاب الإقنـاع، وكتاب أعـلام النبوة ،

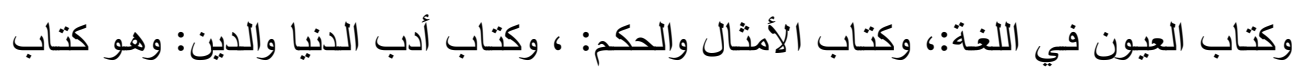

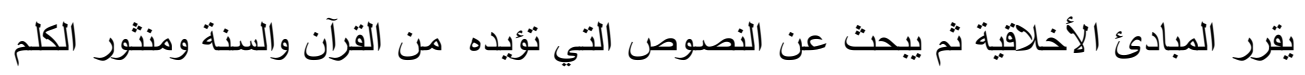
ومنظومها، وهو يمـزج بين تراث العرب وتراث الأمح الأخرى بمادة غزيرة وتلاحم مستمر ، 


\section{الباحث/ محمد حسن محمد}

حسن الصياغة والسبك مفيد في التربية والأخلاق، وقد طبع عدة طبعات كما ترجم إلى اللغة التركية وقام البعض بشرحه كالأرزنجاني بحاشية منهاج اليقين في شرح أدب الدنيا والدين، كما اختصره السيوطي. كمان.

كما أن من كتبه رحمه الله كتاب تسهيل النظر وتعجيل الظفر : يتضمن هذا الكتاب موضوعين: أحدهما: الكلام في أصول الخلق من الناحية النظرية. الثاني: سباسة الملك وقواعده: وكذلك من كتبه كتاب الأحكام السلطانية والولايات الدينية(1) 
منهج الإمام الماوردى - رحمه الله - فى النقد

\section{المبحث الثاني}

معالم رئيسية في منهج الإمام الماوردي في النقد:

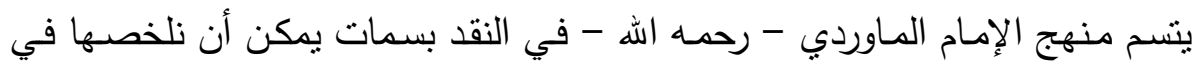

النقاط التالية:

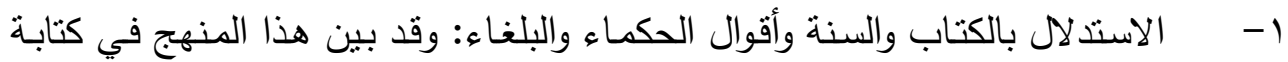

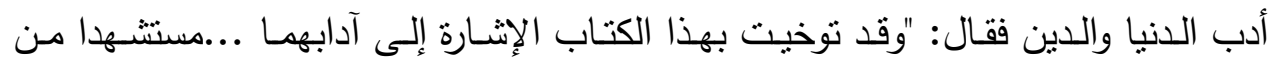

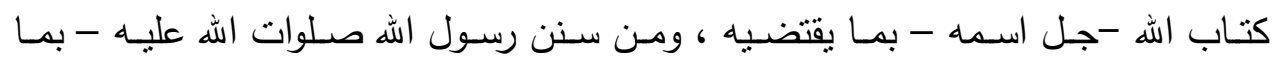

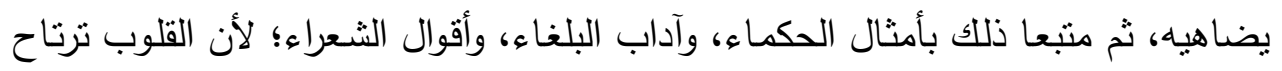

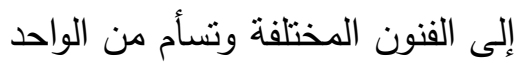

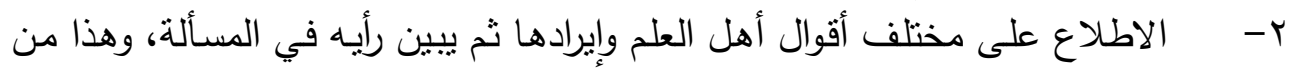
القضايا الأساسية في موضوعية الناقد، وقد ظهر هذا في كتبه كلها في الأحكام السلطانية

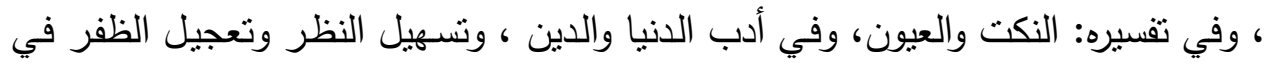

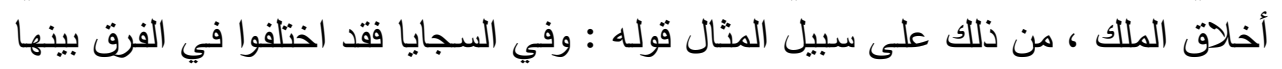

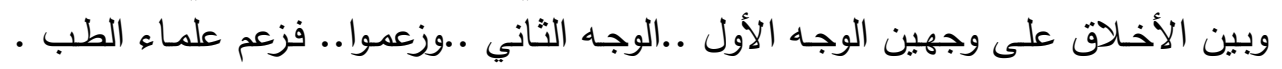

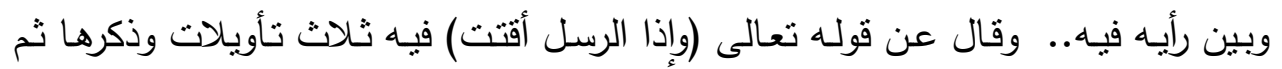

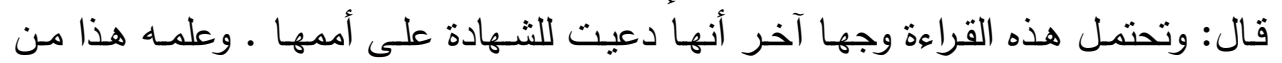

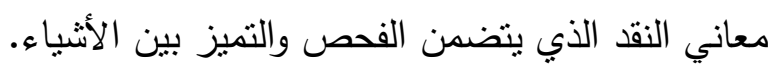

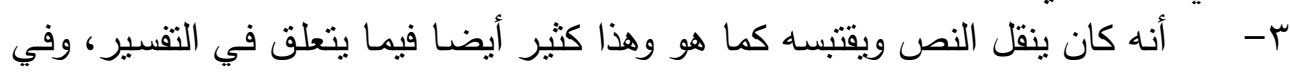

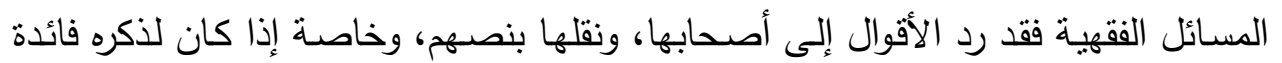

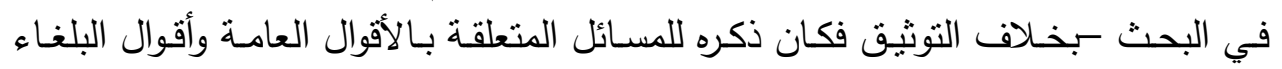
والحكماء فقد كان يقول فيها قال البلغاء أو الحكماء فلم يبين قائليها لعدم الأهمية ولأنها

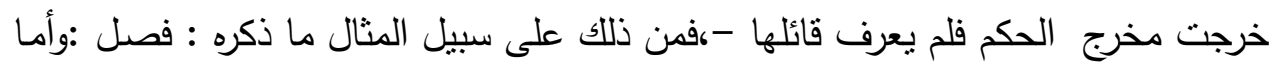

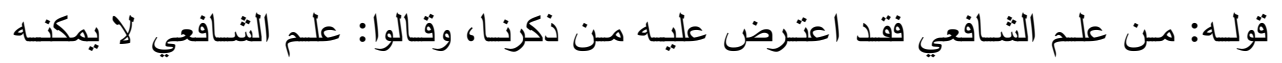

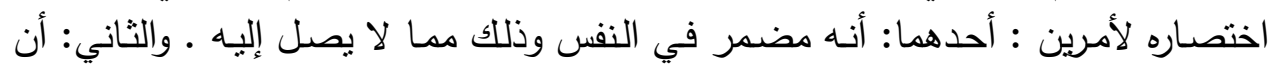

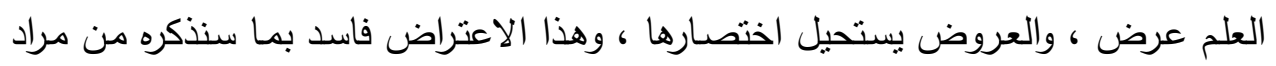

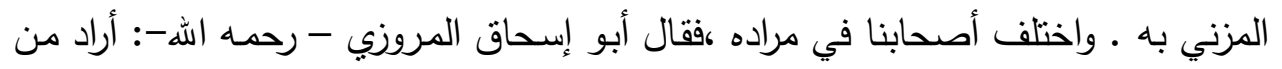
كتب الثافعي فعبر بالعلم عن الكتب، لأنه قد يوصل بها إلى العلم كما قيل في تأويل قوله إله

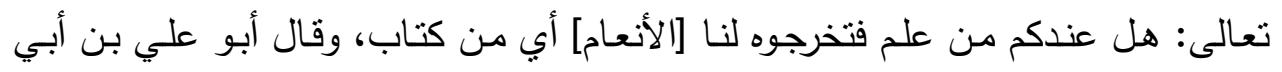

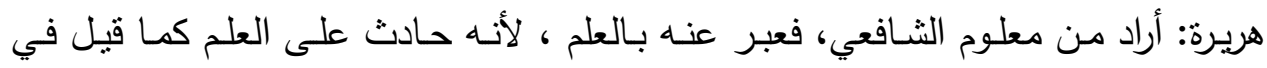

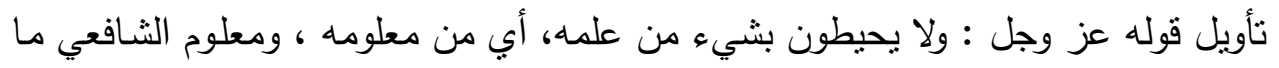


أخذ عنه قولا ورسما. وفائدة هذا النقل يثير إلى الأمانة العلمية التي يتمتع بها الماوردي رحمه الله ، وهي من أهم أخلاقيات منهجية النقد.

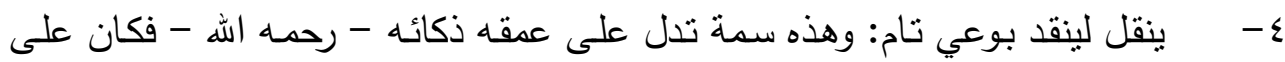

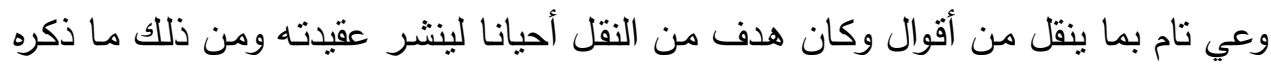

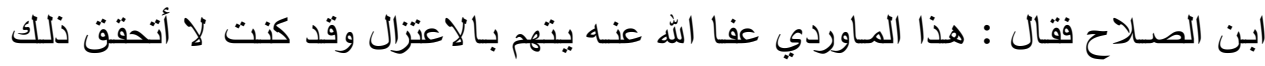

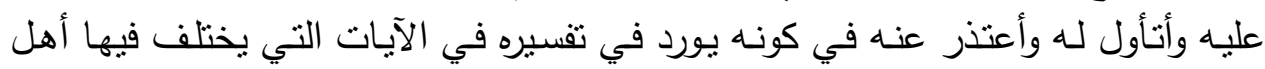

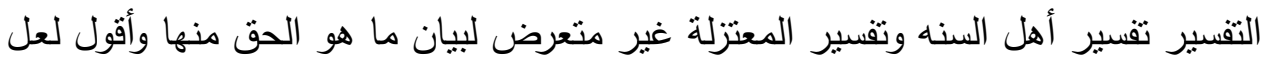

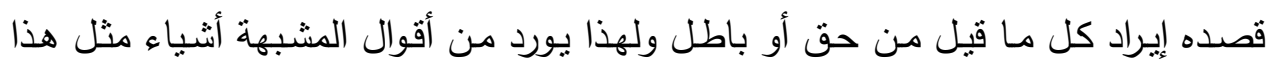

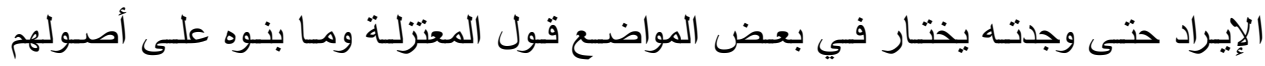

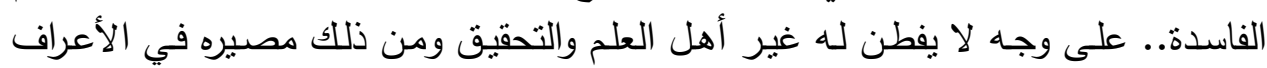

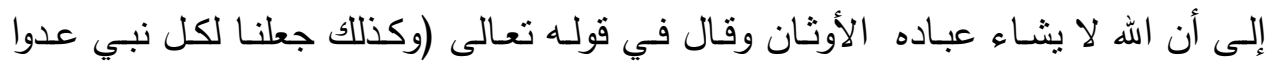

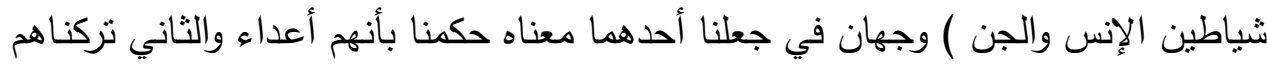

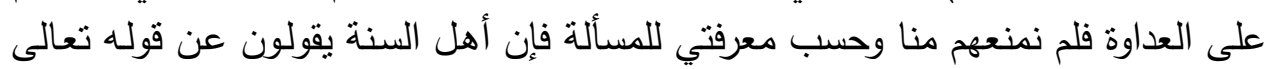

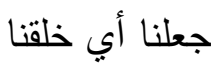
0- الصدق في النقد وتحري الحق:

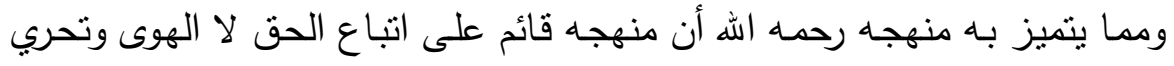

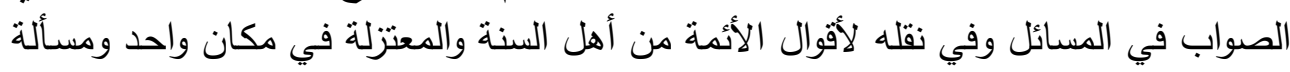

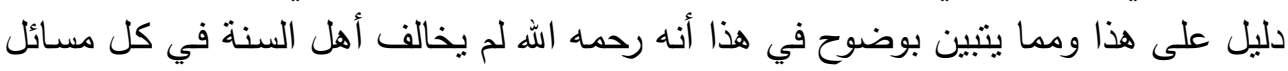

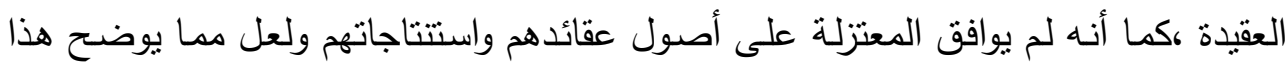

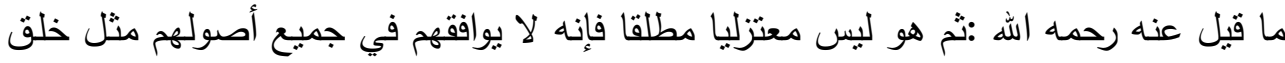

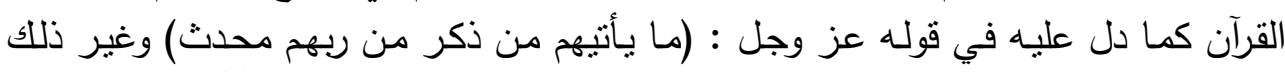

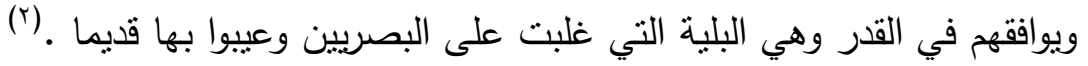
1- تتوع مجالات النقد :إذ نقد أصنافا مثتوعة ومجالات عدة فنقد طلبـة العلم والعلمـاء ونقد نفسه ونقد العوام ونقد المناهج وبسط سلطان نقده على الحاكم والملوك وهذا ما أفردت لـه له

\section{فقرة خاصة.}

V- كثرة شواهده واستد لاله بها عند نقده لقضية معينة وقد يكثر من الشواهد ويقلل بحسب ما

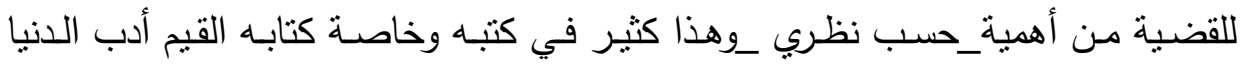

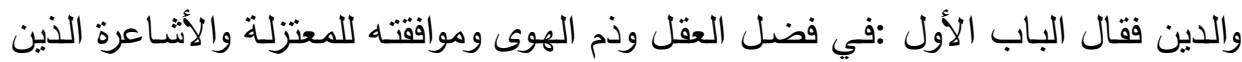

(؟)

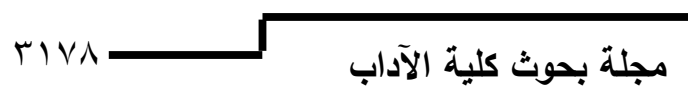


منهج الإمام الماوردى - رحمه الله - فى النقد

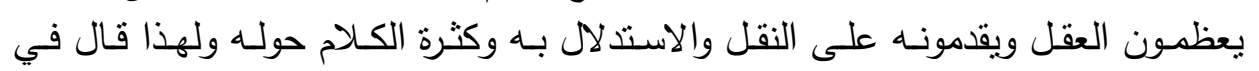

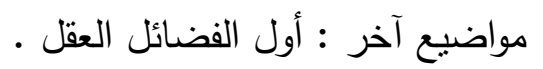

ᄉ- تأثر نقده بعقيدته إلى حد ما كما في تأويل السابقة التي ذكرته آنفا، وقد حاول التدليس

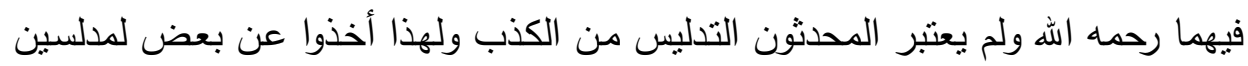

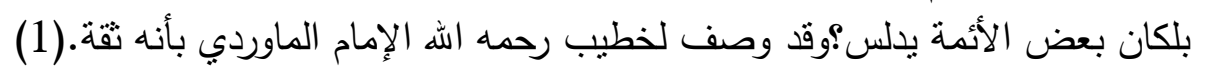

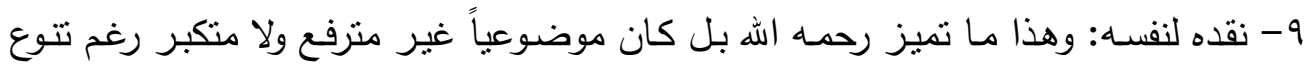

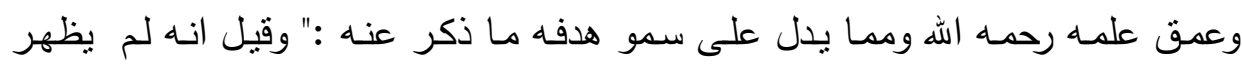

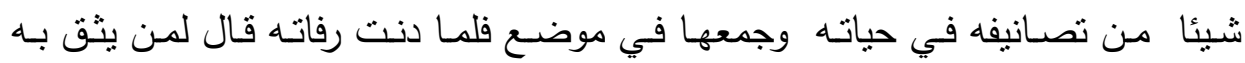

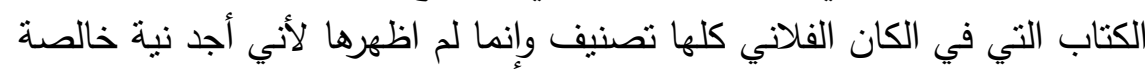

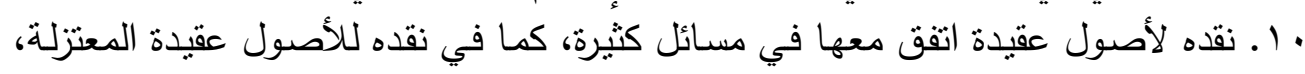

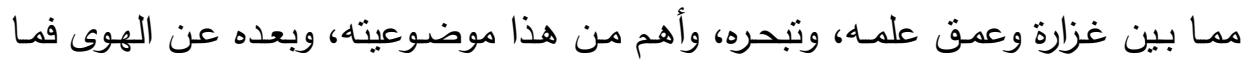

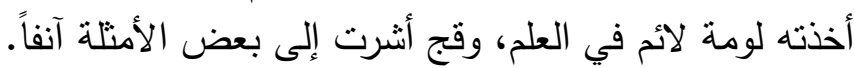

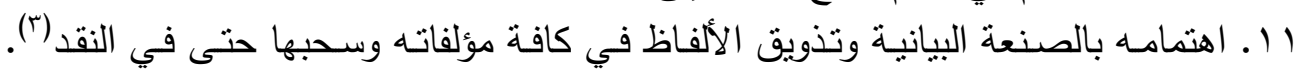

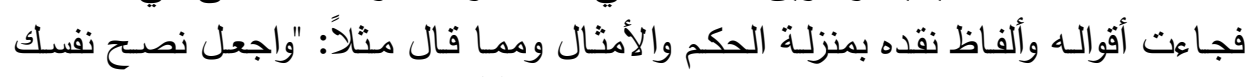

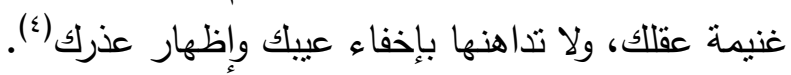

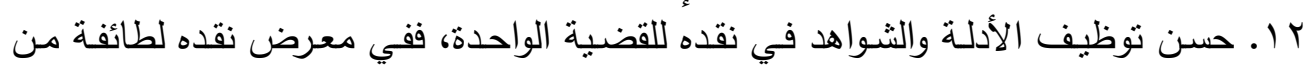

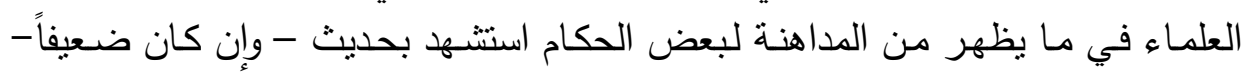

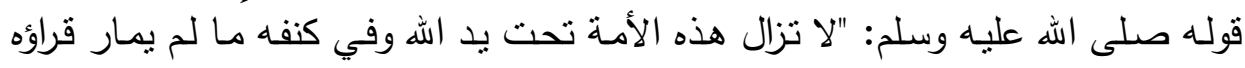

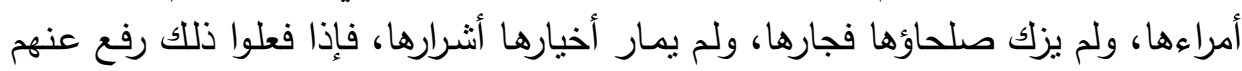

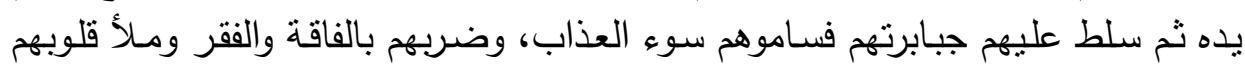
رعباً.

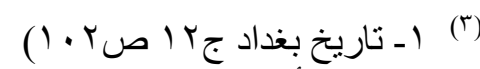

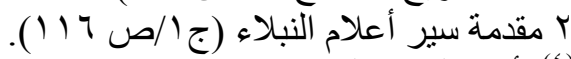

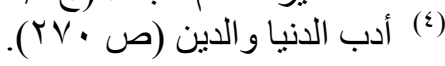




$$
\text { المبحث الثالث: أسباب وأهداف النقد عن الإمام الماوردي }
$$

1- الخطأ في الاستدلال من بعض العلماء، وقد بين في رده على بعض العلماء قوله:

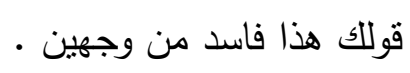

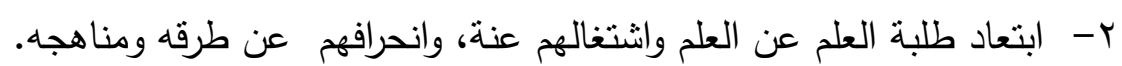
r- الخطأ في فهم التعامل مع الحياة ، ولهذا الف كتبه ادب الدنيا والدين ع- الخطأ في التعليم والنقد بين الحكام والمحكمين، ولهذا الف كتبه الكثيرة ومنها نسهيل

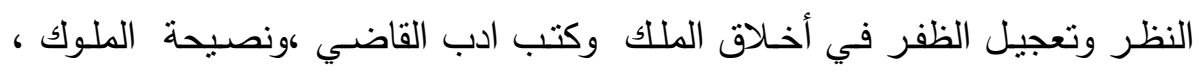

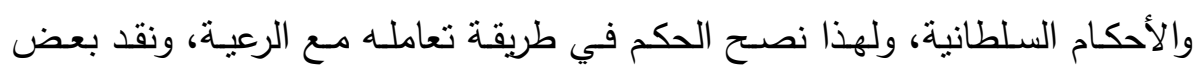

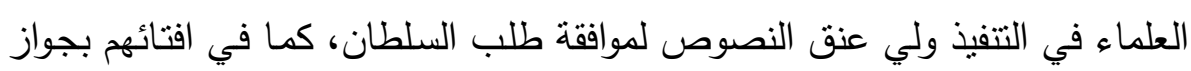
التسمية بملك الملوك.

ومن الأهداف للنقد عند الإمام الماوردي : 1 - القيام بواجب الله تعالىى

فقال رحمه الله : وينبغي لمن انزل منزلة المستشار واحل محل النصاح المواد حتى

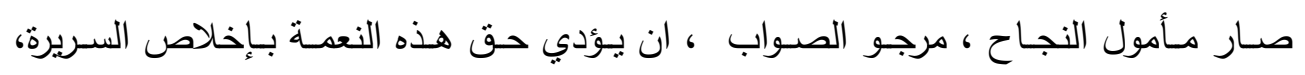

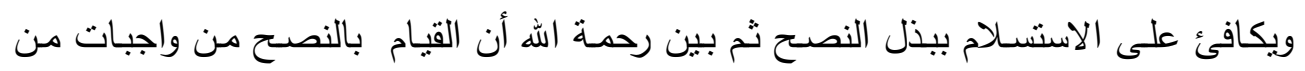

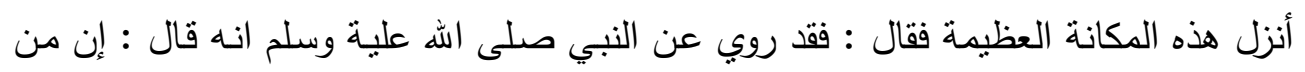
حق المسلم على المسلم إذا استتصحه أن ينصحه .

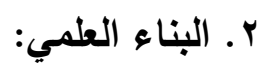
ويقوم البناء العلمي عن طريق مناقثـة النصوص والآراء إذ نزيد المناقثـة من البناء العلمي والمعرفي، وإن المناقثة هي إحدى معاني النقد في اللغة ولهذا قالوا: ومن اقدنك فلاناً

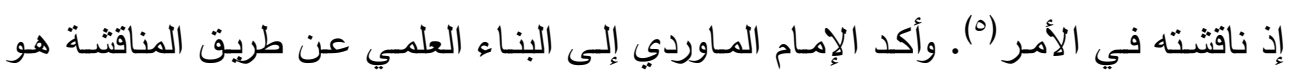

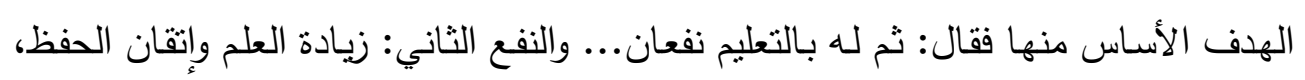
فقد قال الخليل بن أحمد: اجعل تعليمك دراسة لعلمك، واجعل مناظرة المتعلم تتبيها على ما

$$
\text { (0) أحمد عمارة: في النقد الأدبي (ص 0) }
$$

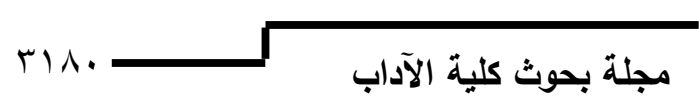


منهج الإمام الماوردى - رحما الله - فى النقا

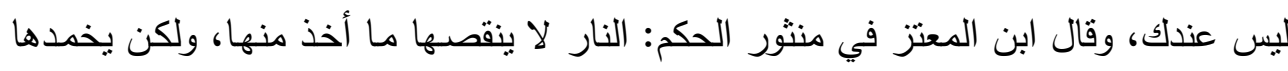

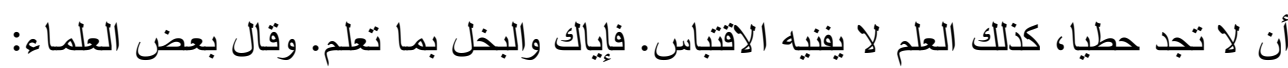
علم علمك وتعلم علم غيرك، فَذذا أنت قد علمت ما جهلت وحفظت ما علمت".

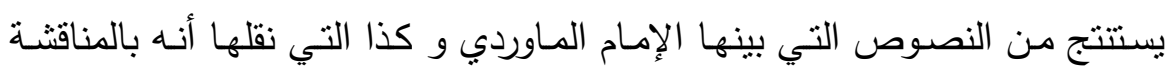
والني تعتبر من أنواع ومعاني النقد بينتتج منها أنها تهلف إلى البناء العلمي والمعرفي. r. بثف الأخطاء وسرعة علاجها: ومن أجمل ما ضربه الإمام الماوردي في هذا الثنأن قوله رحمه الله: "ومما أنذرك

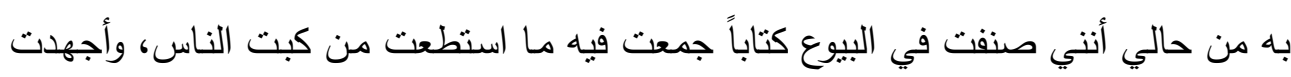

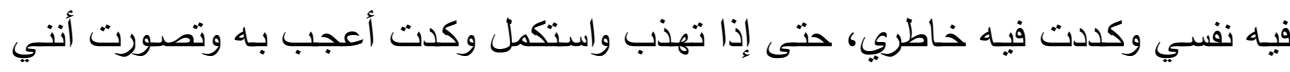

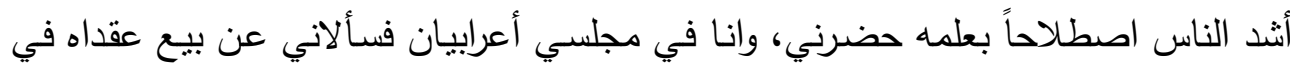

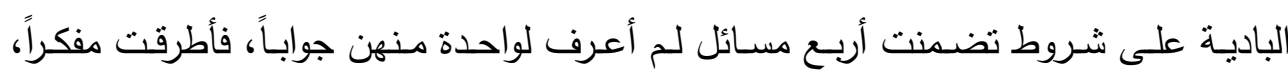

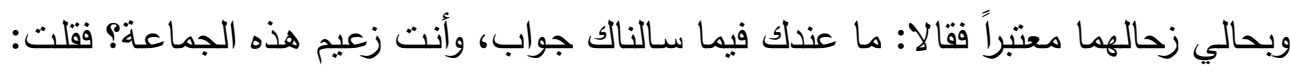

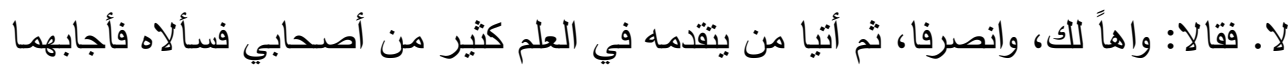

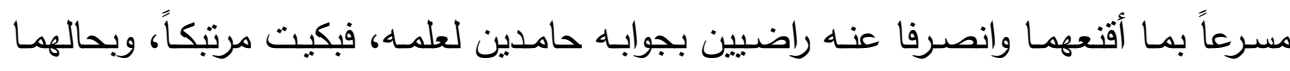

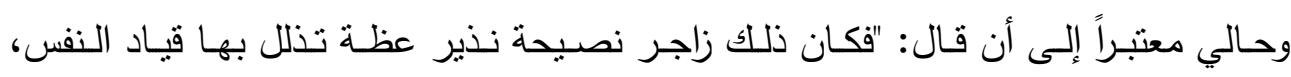

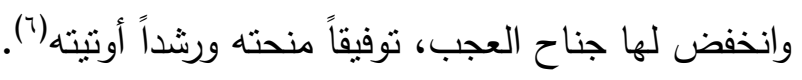

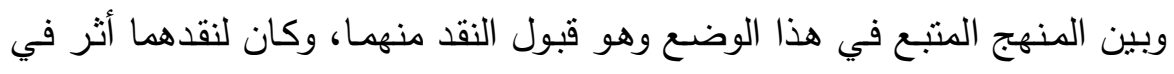

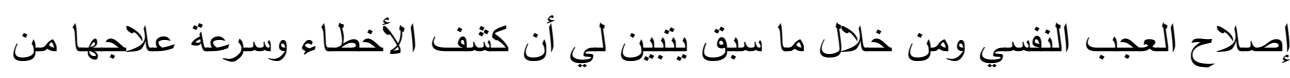
أهدف النقد التعليمي.

$$
\text { (7) ( أدب الدنيا و الدين (ص or). }
$$


إن الإصــلاح التربـوي هـو "النظـر في النظـام التربـوي القـائم بمـا في ذلـك النطـام التعليمي ومناهجهـ مـن خـلا إجراء الدراسـات التقويميـة ثم البدء في عمليـة الإصـلاح وفق

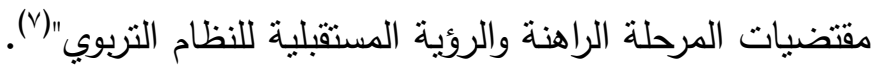
إن الإصلاح التربوي إذا عم واستوفى حقه عم الخير على كافة الجوانب، وغذا فسد وانحرف ناءت الأمة عن مكانتهما وتلقفهما الجهل بدينها ومركزها بين الأمم، وإن كل مجانبة ترجع إلى الخطأ في التربيـة سواء كان الخطأ في جانب التربيـة العقائديـة أو الأخلاقيـة أو الاجتماعية، وكل هذه الجوانب مرجعها إلى عدم أو سوء الصلاح التعليمي.

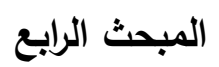

أخلاقيات وضوابط النقد عند الإمام الماوردي

تتمثل الأخلاقيات في الجوانب التربوي في مجالات متعددة من أهمها ما يلي: أولاً: أخلاقيات وضوابط أهداف النقا وغايته من خلال الضوابط التالية.

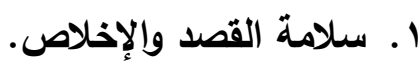

1-لكل عمل يقوم به الإنسان مقصد، وأن من أخلاقيات النقد من منظور التلربية الإسـامية

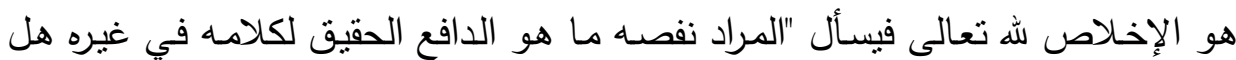
هو الإخلاص والنصح لله ورسوله أم هو خفي أم جلي أم هو حسد وكراهة له (^).

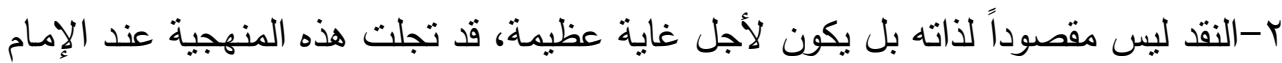
الماوردي رحمه الله في أقواله وأفعاله فمن أقواله ما ذكره في مقدمة كتابه النفيس نصيحة

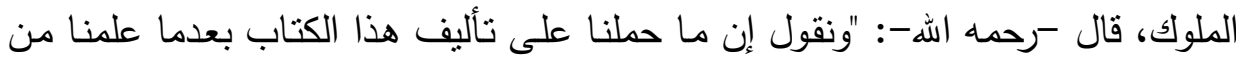

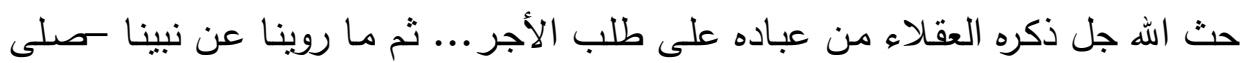

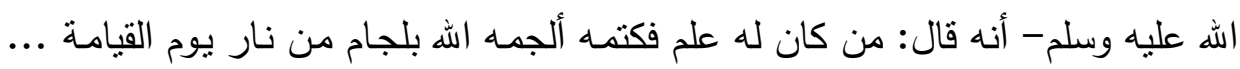
ثم روينا عنه أنه قال: الدين النصيحة. وكان يقال من كتم السلطان نصيحته والأطباء (V) (أحمد حسين وعلي الجمل: معجم المصطلحات التربويـة المعرفة في المنـاهج وطرق التدريس

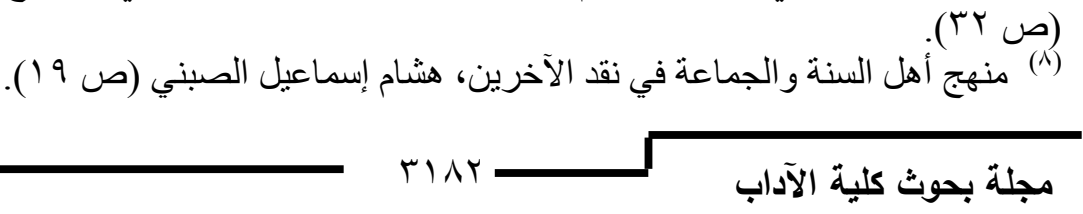


منهج الإمام الماوردى - رحمه الله - فى النقد

مرضده والإخوان بثه فقد خان نفسه، ففي نصيحة السلطان نصيحة الطافة وفي نصيحة الكافة هداية إلى مصلحة العام بأسره(9).

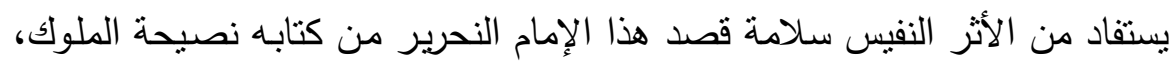

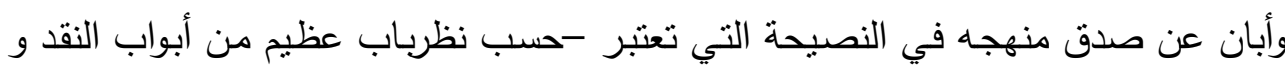
أفضل أبوابه فبين - رحمه الله - الأصل من هذه النصيحة ألا وهي "الحرص على فئل هداية

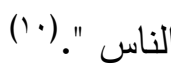

ومن صسور سـلامة القصد أن يكون النصـح لوجـه الله تعالى، قال رحمـه الله تعالى

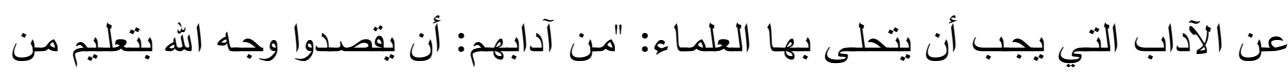

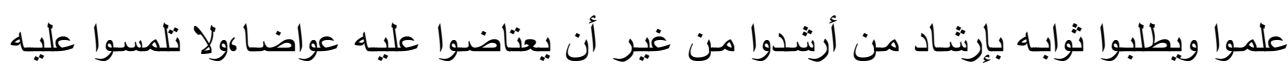
(') (1)

ومن صور سـامة القصد إخلاص السربرة قال رحمه الله وإيانا: "وينبغي لمن أنزل

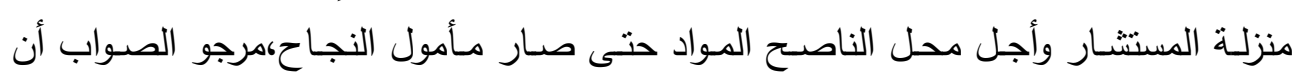
يؤدي هذه النعمة بإخلاص هذه السريرة،ويكافي على الاسنسلام ببذل النصح. (ז'آ) وقال رحمـه الله تعالى: "وربمـا أبطرتـه المشـاورة فأعجب برأيـه فاحذره في المشـاورة

فليس للمعجب رأي صحيح ولا روية سليمة.(r) ولهذا خاف العجب فكاد أن يرمى كتبه في النهر .

r - الورع والعدل والإنصاف:

العدل كما يقول الإمام الطبري فقال: الوسط: العدل. وذللك معنى الخيار لأن الخيار

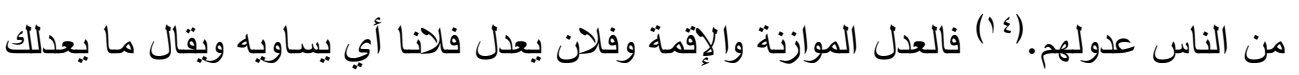

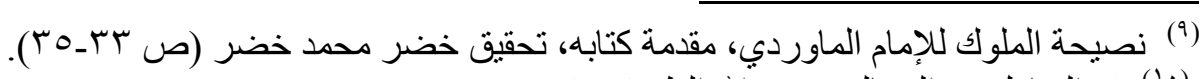

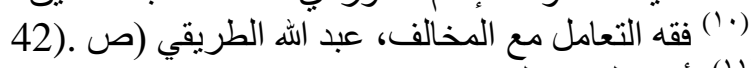

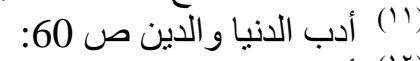

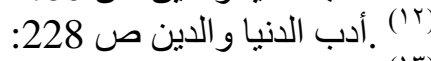

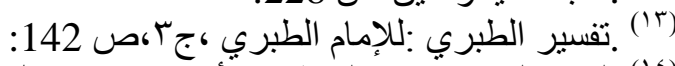

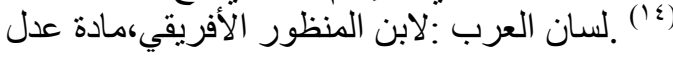




\section{الباحث/ محمد حسن محمد}

عندنا شيء أبي ما يقع عندنا شيء موقعك، وعدل المكاييل والموازين: سوها وعدلت فلانا

بفلان إذا سويت بينهما. (10)

فالعدل توسط، وهو بهذا المعنى يعيد التكامل إلى الإنسان ولاينظر اليه بعين واحدة

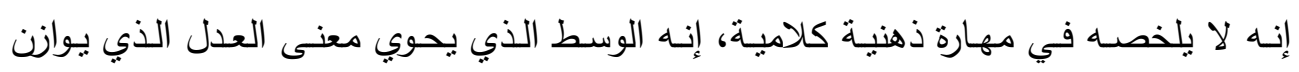

بحكمة بين الثيئين. (17)

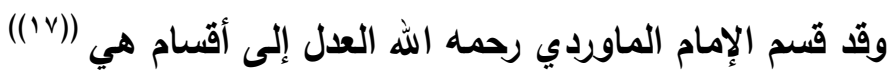

أولا: عدل الإنسان في غيره، و يكون بثلاث أحوال:

ا. . عدل الإنسـان فيمن دونه: كعدل السلطان مـع الرعية، و المعلم مـع تلاميذه و هذا

$$
\text { بكون بأمور : ألمان }
$$

- - أنباع الميسور فهو أدعى للألفة و المودة.

- حذف المعسور ، و هو أدعى للتعامل بالرفق.

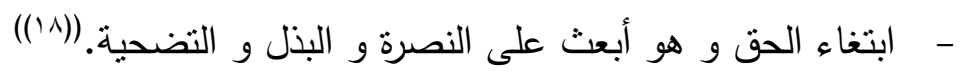

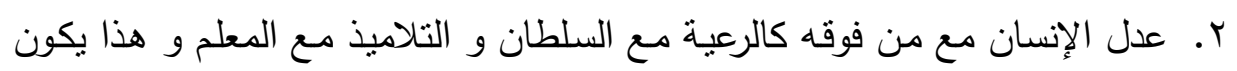

$$
\text { بما يلي: }
$$

$$
\text { - - - اخلاص الطاعة فهو أجمع للثمل. }
$$

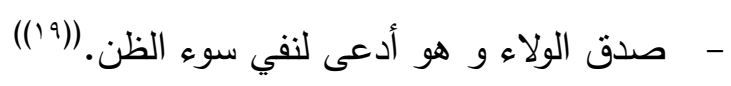

r. عدل الإنسان مع أكفائه و ذلك كعدل الإنسان مع إخوته في كافة الأحوال و يكون

$$
\text { بأمور : بأ }
$$

- - ترك الاستطالة على الغير تكبرا و زهوا و تعاليا أو نرفعا.

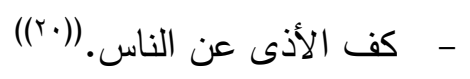

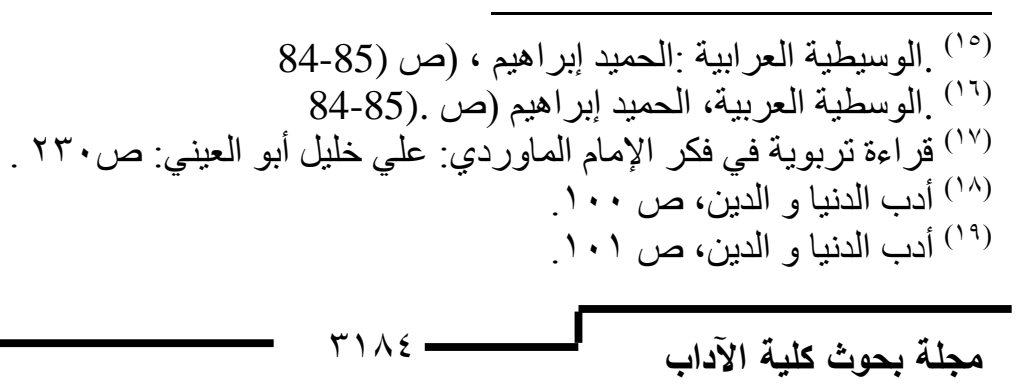


منهج الإمام الماوردى - رحمه الله - فى النقا

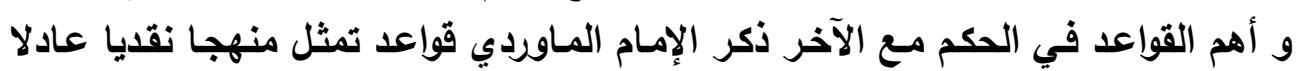

I. الإنصاف للعدو: يعضنا الإمام الماوردي عند نظرية في العدل نعتبر كحكمة في العدل

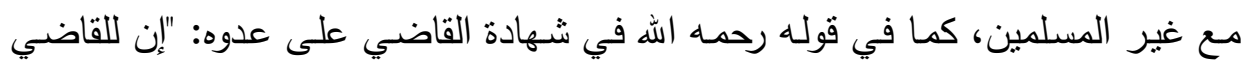

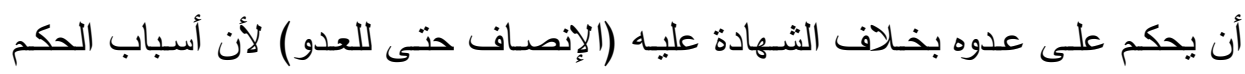

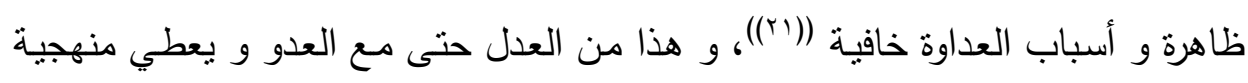
في الورع نقد المخالف في العموم، و في نقد العدو .

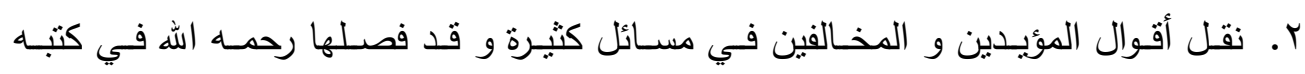

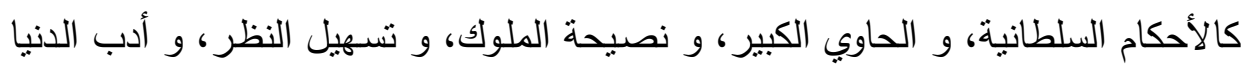
و الدين، و النكت و العيون (التفسير) حيث نقل أقوال المخالفين له و المؤيديدين.

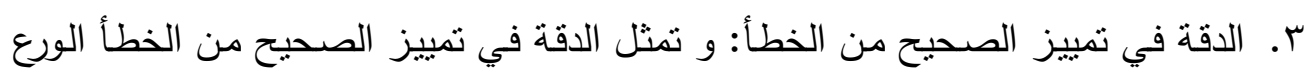

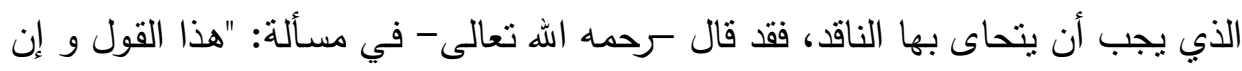

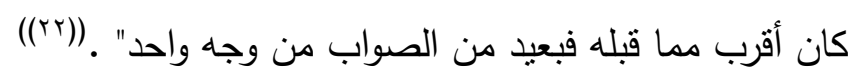

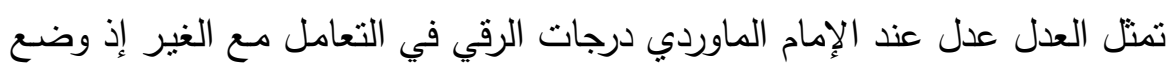

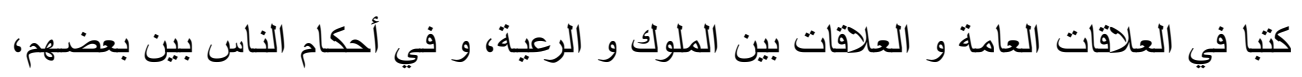

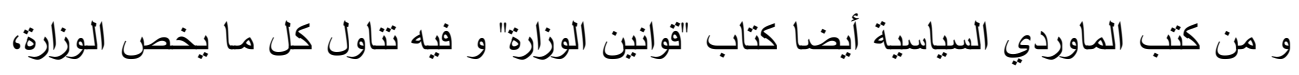

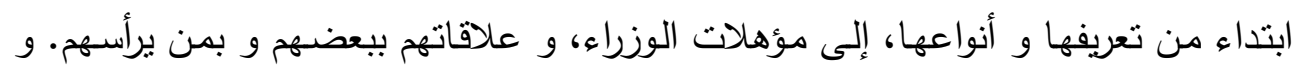

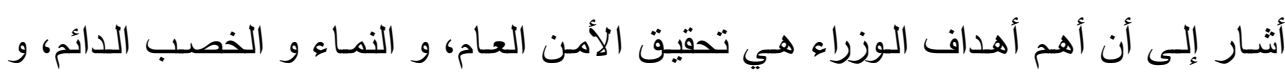

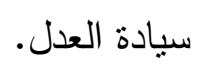

وبين في كتاب أدب الدنيا والدين علاقات المتعلمين مع المعلمين، وآداب كل واحد

منهم، وأعطى لكل منهما ما يجب له وما يجب عليه و كان رحمه الله عدلاً في ذللك.

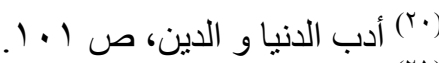

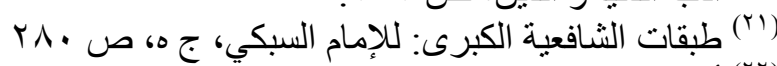

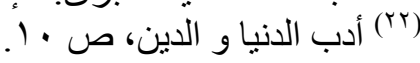

مجلة بحوث كلية الآداب

M) 
أولا: الموضوعية: إن قيام النقد على الصدق و الإخلاص في مقصد فئه الناقد، يدفعه إلى القيام بالنقد بموضوعية تجعل العمل النقدي يجني ثمارهو آثاره الحميدة، تتمثل صور

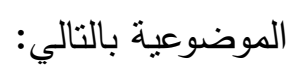

ا. التجرد من الهوى و الذاتية: فالهوى ميل النفس إلى الثهوة و قيل في سبب تسميته بذلك

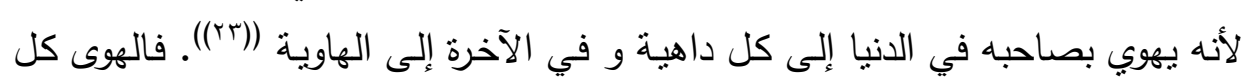

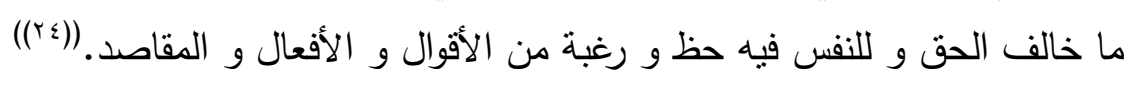

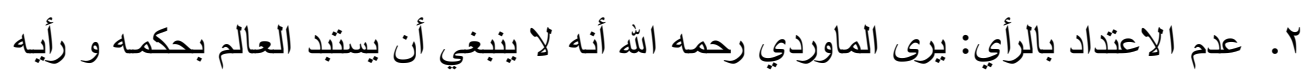

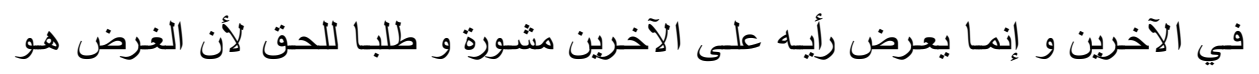

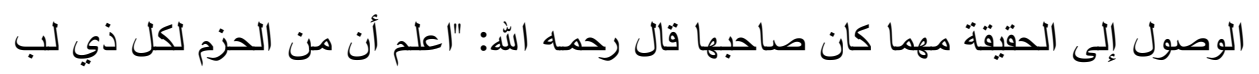

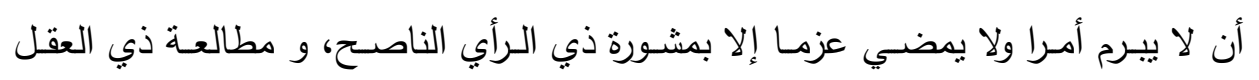

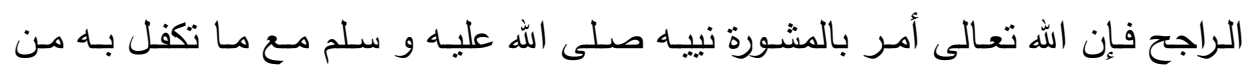

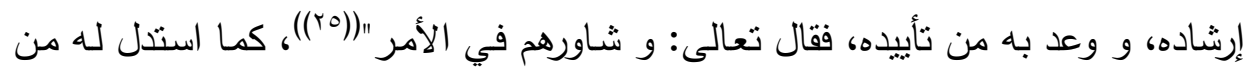

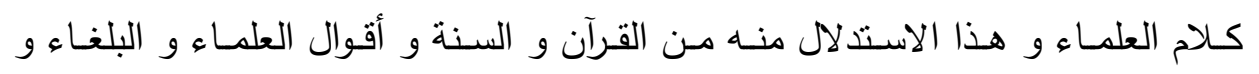
غيرهم، و من ذلك قوله: "و قال بعض البلغاء: من حق العاقل أن يضيف إلى رأيه آراء

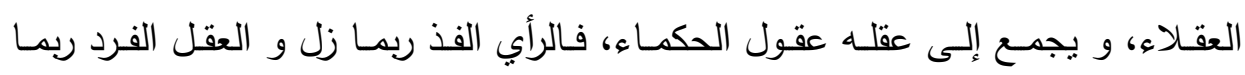

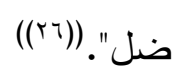

r. أن الرجال تعرف بـالحق لا العكس. فالحكم و النقد و التقويم يكون بحسب الناص، لا بحسب قائله، و هو من أرقى صور الموضوعية، سطر الماوردي عن هذه الفقرة بحكمة

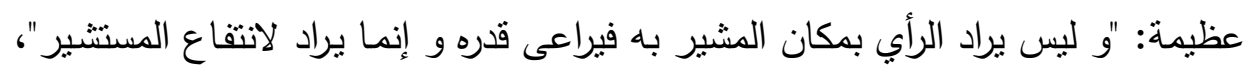

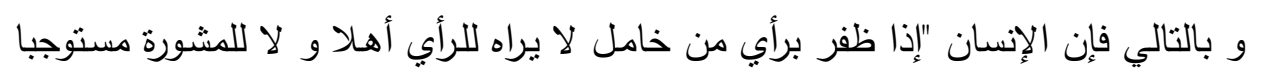

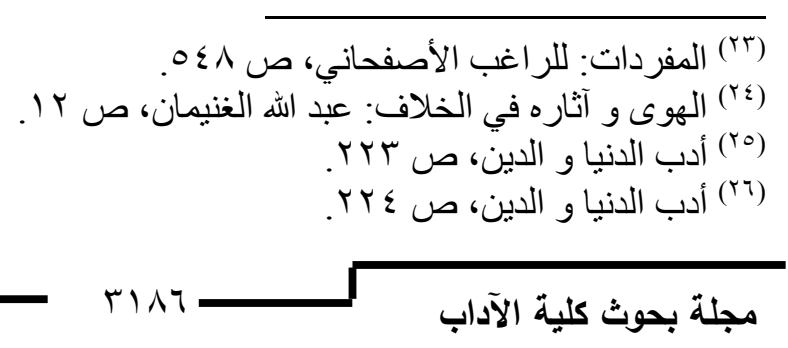


منهج الإمام الماوردى - رحمه الله - فى النقد

اغتتمه عفوا فإن الرأي كالضالة تؤخذ أين وجدت، ولا يهون لمهانة صاحبه فيطرح، فإن المارده

الدرة لا يضعها مهانة غائصها، و الضالة لا تترك لذلة واجدها".

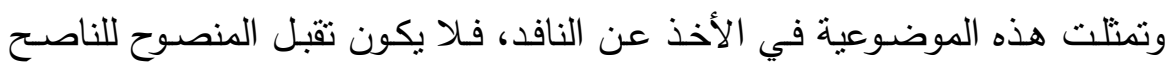

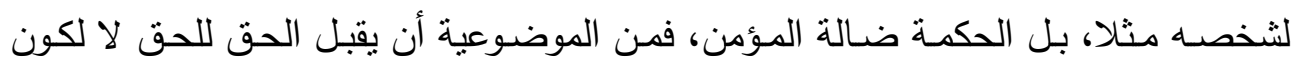

مصدره شخص معين.

ع. الأمانة: قال رحمه الله تعالى: "ولا عذر لمن استشاره عدو أو صديق أن يكتم رأيا و قد

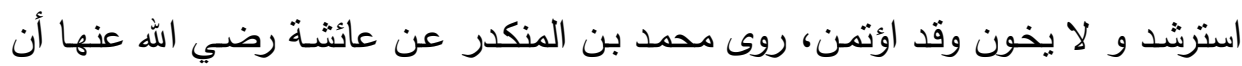

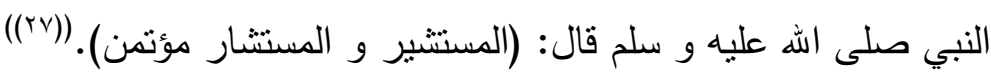

0. فهم المصطلحات الطرف الآخر : و من الصور المهمة في ضوابط و أخلاقيات منهجية

النقد أن يفهم المصطلحات الرأي الآخر فـلا ينقد بنـاء على مصطلحه هو، و و الآخر

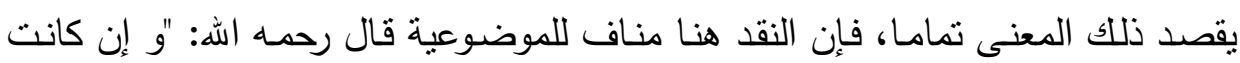

زيادة اللفظ على المعنى دليلا لسوء ظن المتكلم بفهم السامع كان استخراجه أسـهل و إن لمان

كان تقصبر اللفظ عن المعنى لسوء فهم المنكلم فهو أصسعب الأمسور حالا، و أبعدها

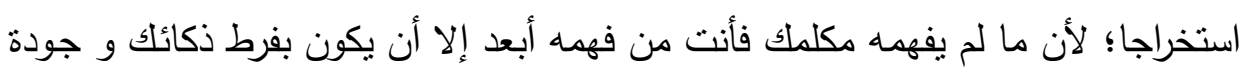

خارطك تتتبه بإثنارته على استتباط ما عجز عنه و استخراج ما قصر فيه فتكون فضيلة

الاستيفاء للك و حق التقدم له.(r)(r)(

ثانيا: الرفق و المداراة: من أهم ضوابط النقد، إذ النقد كما في معانيه اللغوية إيقاع

الألم فهو في أصله صعب على النفس، فوجب أن يكون الرفق و المداراة مصحوبة مـع النقد،

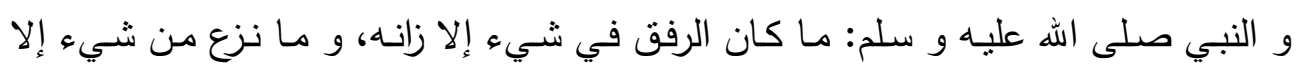

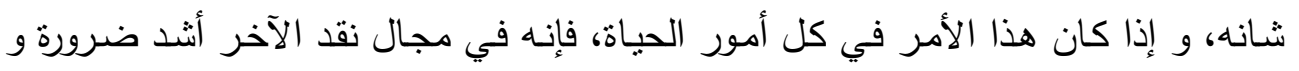
حاجة، و أما الإمام الماوردي فكان رفيقا هادئا، و الذي ينظر في آناره العلمية و العملية تجد معاني الرفق تتنقل بين سطور كلماته، و من الأدلة على ذللك ما ذكره عنه ابن كثير رحمه لئم

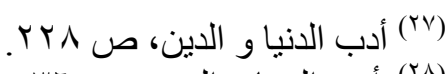

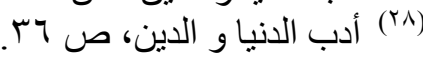


الله جميعا: "و كان حليما وقورا أدبيا لم ير أصحابه ذراعه يوما من الدهر من شدة تحرزه و

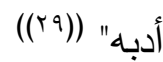

ثالثا: العلم. من ضوابط منهجية النقد أن يعلم الناقد بأصول العلم الذي ينقضسه، ولا

يكتفي بالإلمام العام، بل إذا شرع في نقد نظريـة أو فكرة أو مدرسـة أن يكون على علم بما بنقد، والإمـام المـاوردي رحمـه الله نقد علمـاء الطب بمنهحيـة علميـة، وناقتـهم بلغتهم فقال "وزعم بعض العلمـاء الطـب أن السـجايا والأخـلاق تابعـة لمـزاج البدن في أحوال الطباعـة

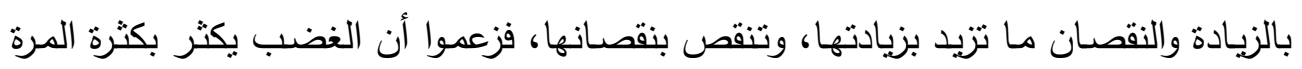
الصفراء... فإذا اعتدلت فيه هذه الأمزجة اعتدلت أخلاقه (·r).

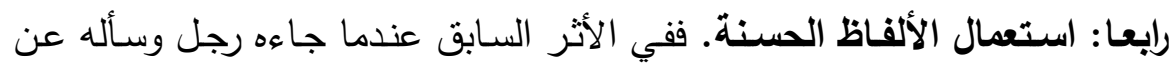

نجم استخدم معه ألطف عبارة في اللفظ ذات المعنى الألطف من لفظها عند طلب السؤال، ومنع أصحابه وتلامذته من النكير عليه بعد سؤاله: "وعجب من في مجلسي من سؤاله وبدر

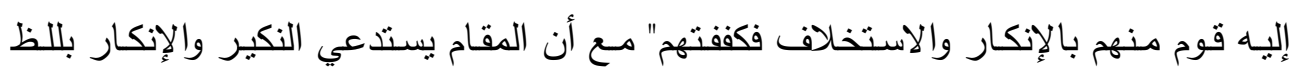

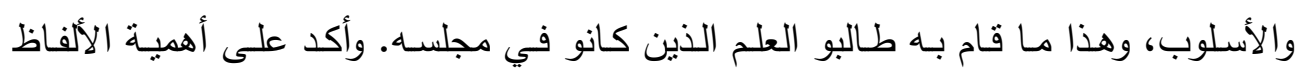

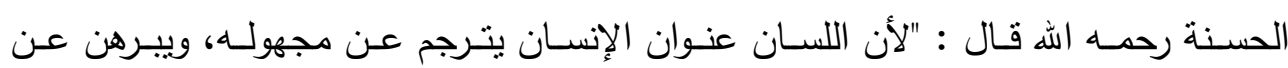
محصوله، فيلزم أن يكون بتهذيب ألفاظه حريا وبتقويم لسانه مليا. روي عن النبي صلى الله عليه وسلم أنه قال لعه العباس: "يعجبني حمالك. قال: وما جمال الرجل يا رسول الله؟ قال: لهال

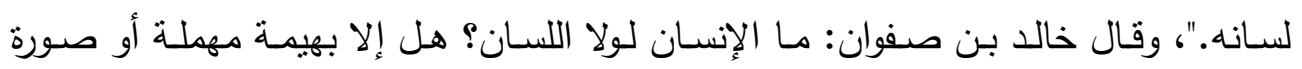
ممنلة؟ وقال بعض الحكماء: اللسان وزير الإنسان... فلا يأني بكلام مستكره اللفظ.."("r)

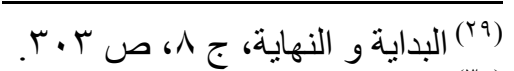

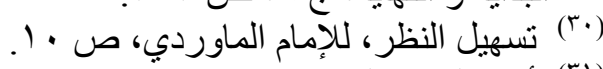

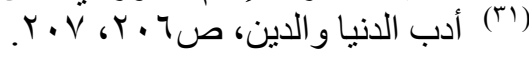

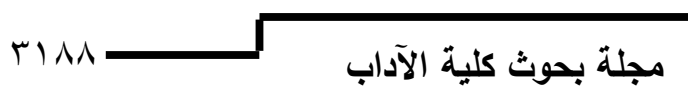


منهج الإمام الماوردى - رحمه الله - فحى النقا

المبحث الخامس: مجالات النقا عند الإمام الماوردي

للنقد عند الإمام أبو الحسن الماوردي مجالات عدة منها:

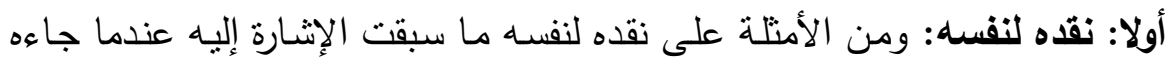

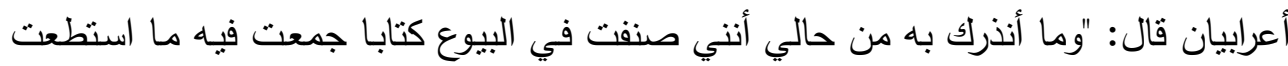

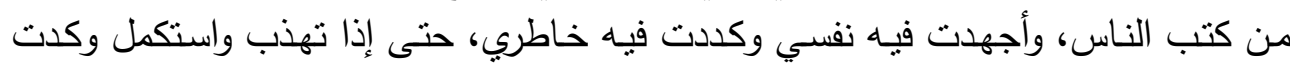

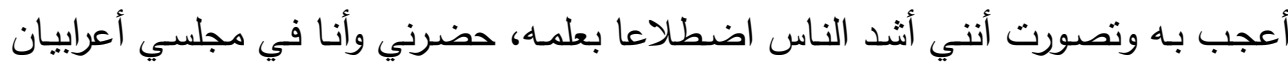

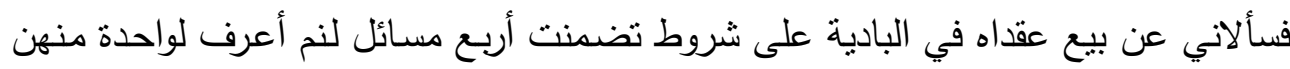

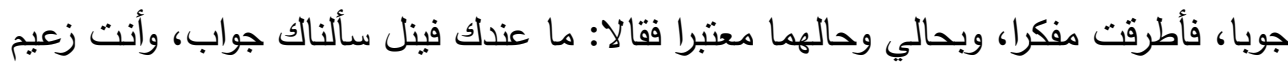

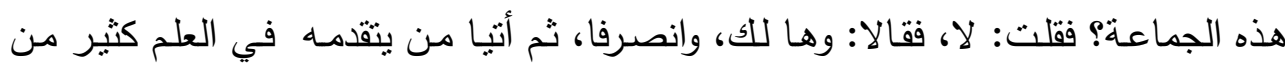

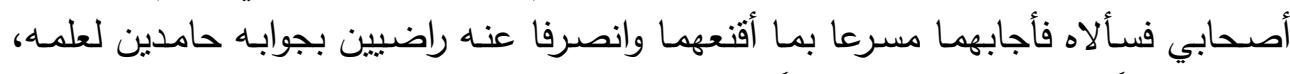

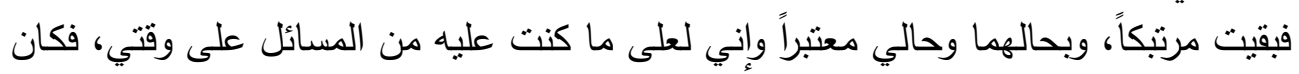

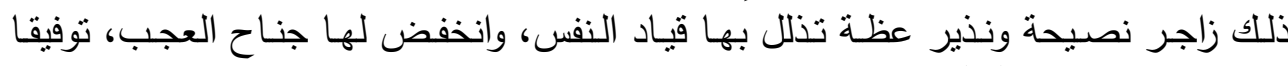

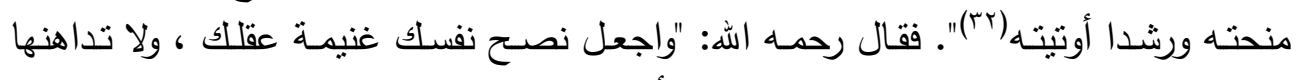

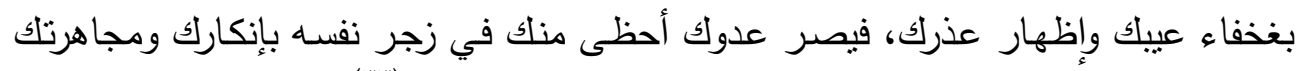

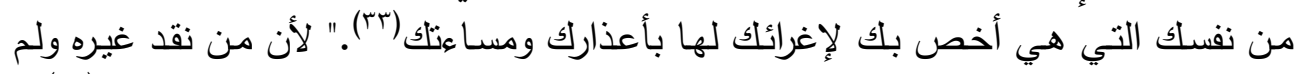

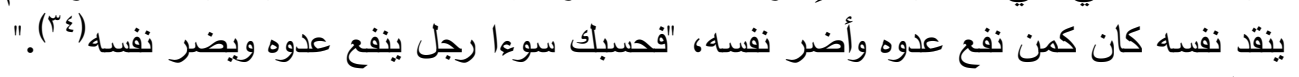
ثنانياً: نقاه للعلماء.

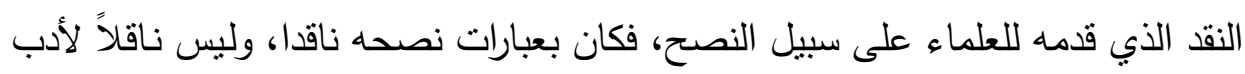

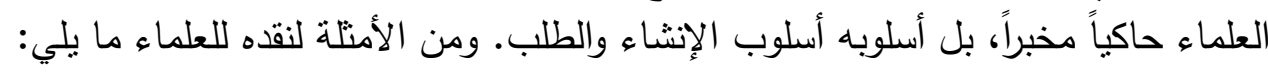

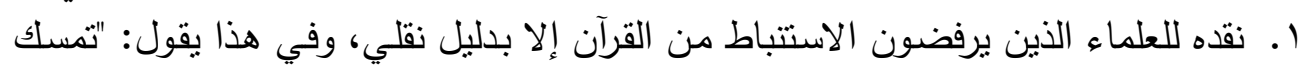

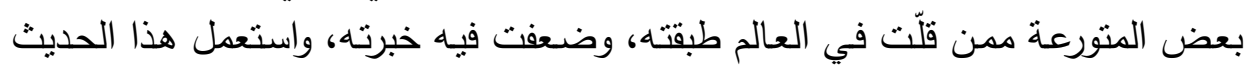

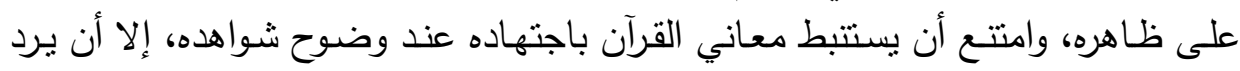

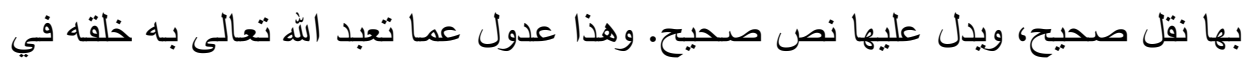

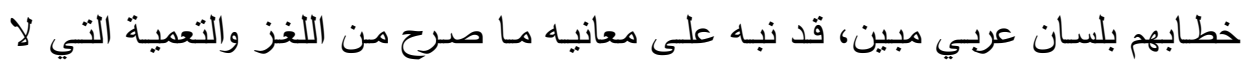

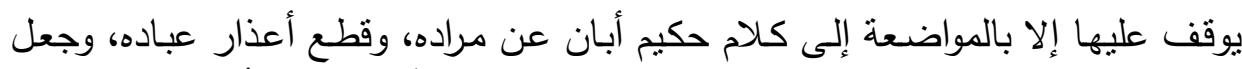

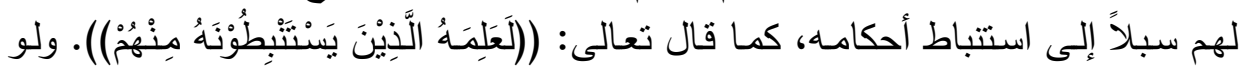
كان ما قالوه صحيحاً لكان كلام الله غير مفهوم، ومراده بخطابه عير معلى معلوم، ولصنار

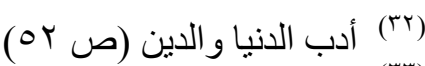

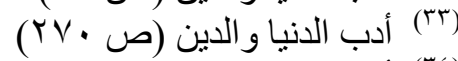

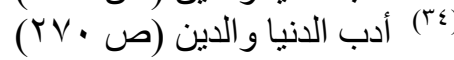


كاللغز المعدى، فبطل الاحتجاج بـه، وكان ورود النص على تأويله معنياً عن الاحتجاج

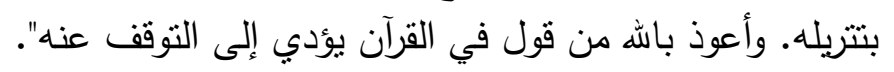

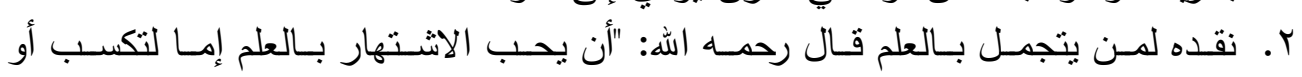

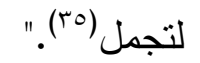
r. نقده لمن لا يعترف بالمذاهب الإسلامية ويقدم علوماً أخرى عليها. قال رحمه الله: ورأيت

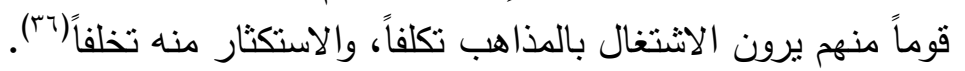

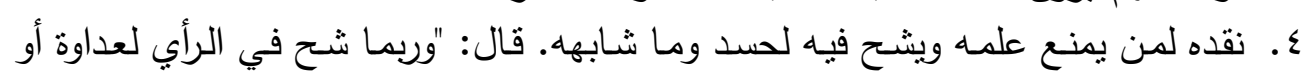

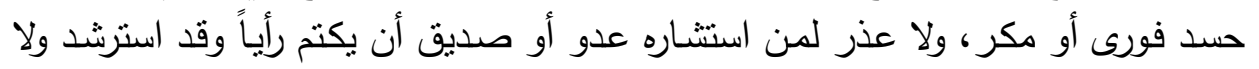

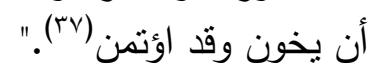

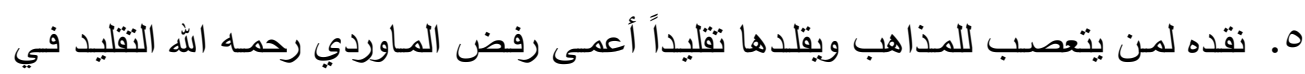

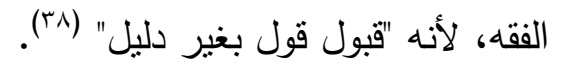

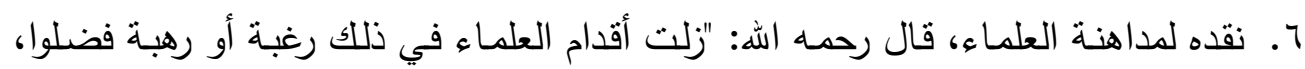

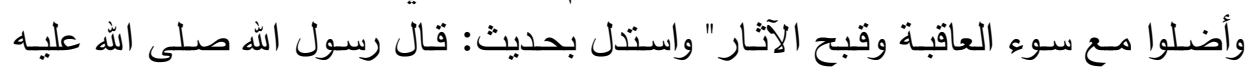

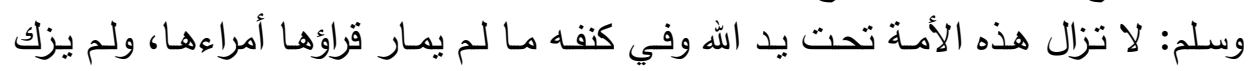

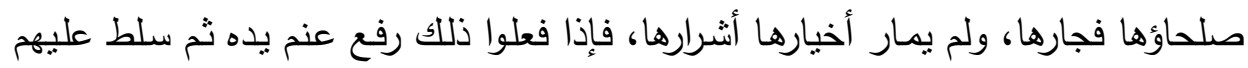

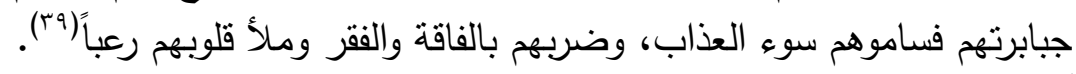
ثالثاً: نقده للمتعلمين

1. نقده لمن يتعلم علوم الجدل ويقدمها على علوم الثريعة وهذا من نقده للمناهج التعليمية

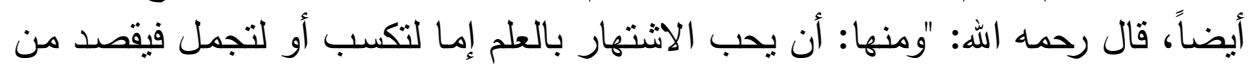

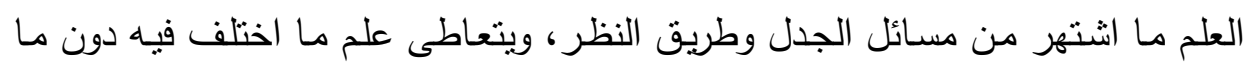

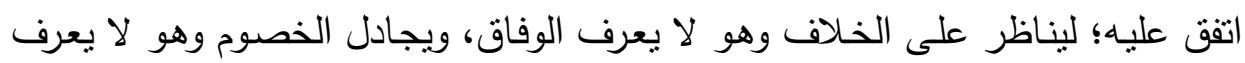

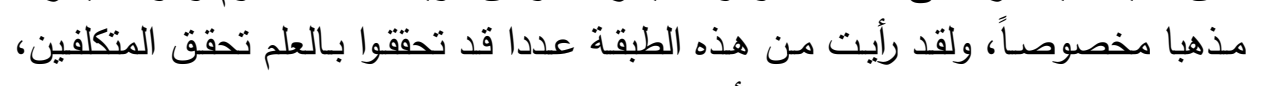

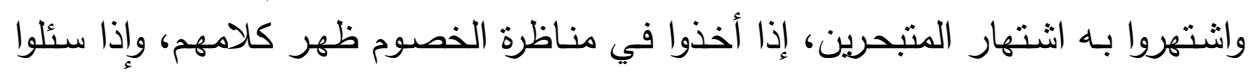

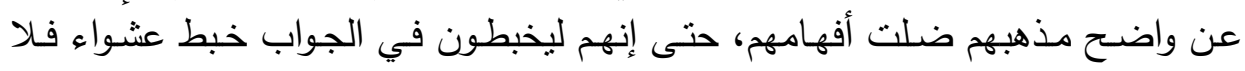

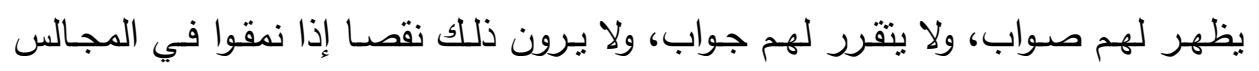

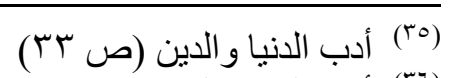

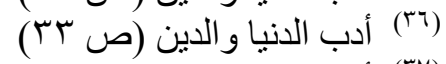

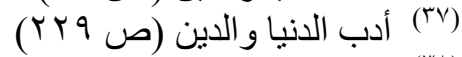

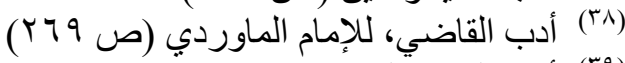

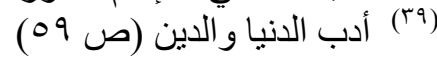

$$
\begin{aligned}
& \text { ए) } 9 . \\
& \text { مجلة بحوث كلية الآداب }
\end{aligned}
$$


منهج الإمام الماوردى - رحمه الله - فى النقا

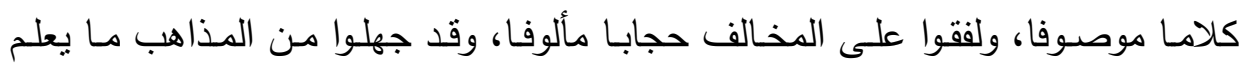

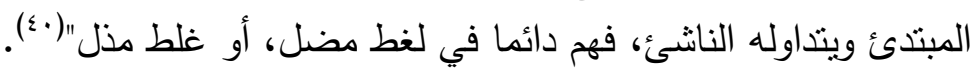

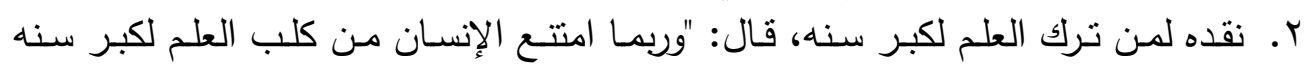

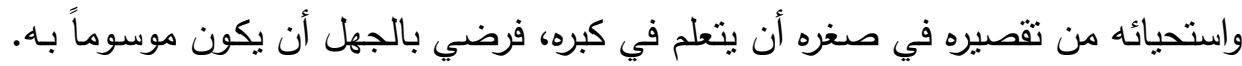

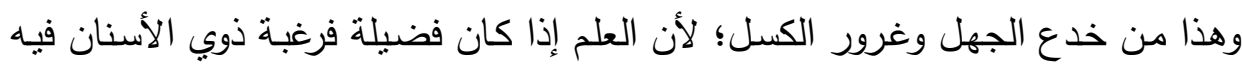

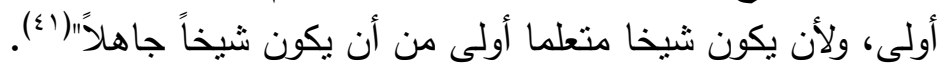

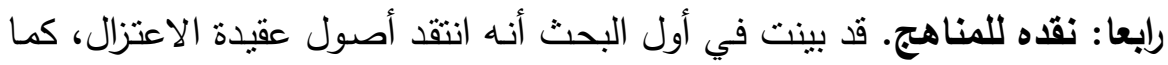

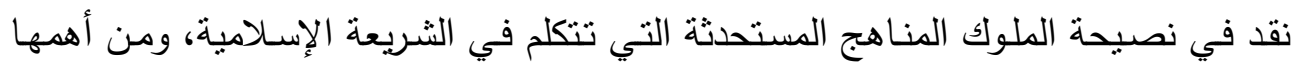

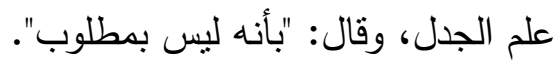

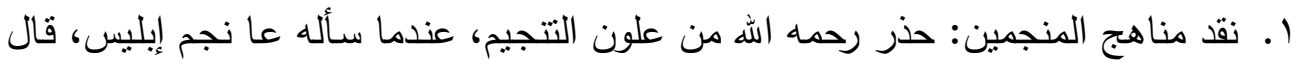

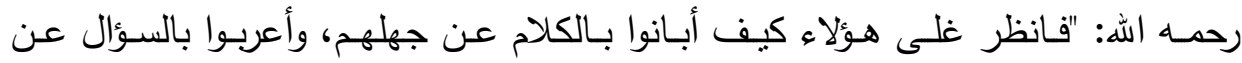

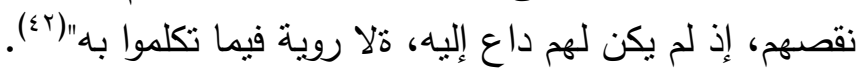

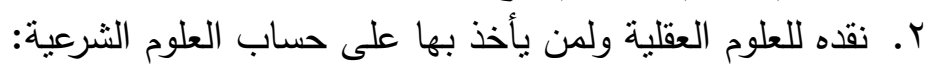

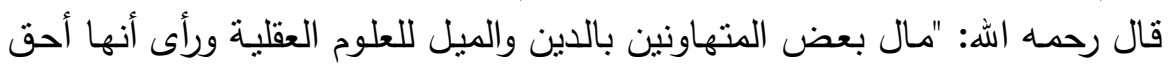

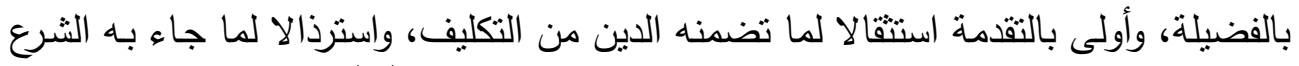

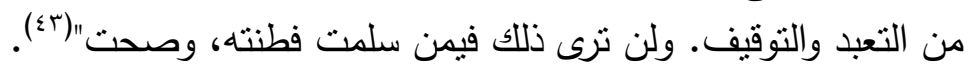

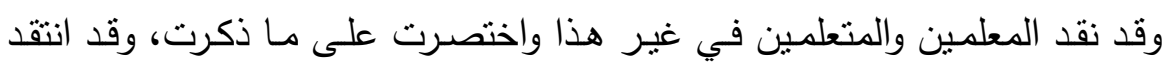

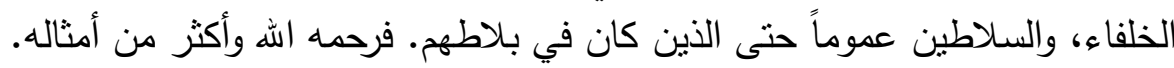

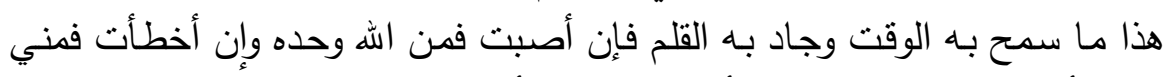

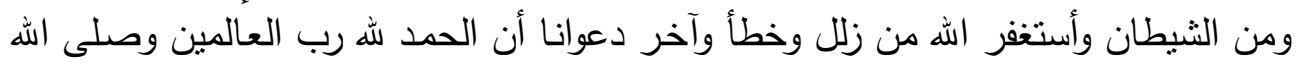
وسلم على نبينا محمد وعلى آله وصحبه أجمعين.

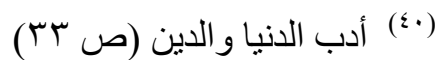

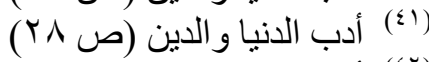

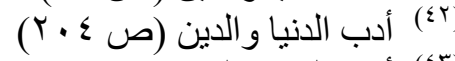

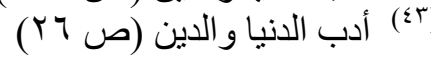




\section{قائمة المصادر والمراجع}

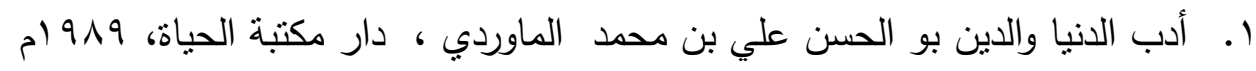
r. طبقات الثـافعية الكبرى ، تاج الدين عبد الوهاب بن تقي الدين السبكي ، تحقيق د. محمود محمد الطناحي د. عبد الفتاح محمد الحلو ، ط ب ، باءع اهـ r. تاريخ بغداد ، أبو بكر احمد بن علي البغدادي، تحقيق بشار عواد معروف، دار الغرب

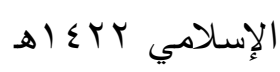

ـ. في النقد الادبي، احمد السيد عمارة، مكتبة الرشد ، سبـ اهـ ه. مـنهج أهـل السـنة والجماعـة في نقد الآخـرين، هشـام الصـيني، المنتدى الإسـلامي، . () \& $1 V$

7. فقه التعامل مـع المخالف؛ المؤلف: عبد الله بن إبراهيم الطريقي؛ حالة الفهرسـة: غير مفهرس؛ الناشر : دار الوطن. V. قراءة تربوية في فكر أبي الحسن البصري الماوردي من خلال كتاب أدب الدنيا والدين.

$$
\begin{aligned}
& \text { علي خليل مصطفى. بيروت - لبنان: دار الوفاء، •99 ام } \\
& \text { ^. الهوى وأثزه في الخلاف - عبدالله بن محمد الغنيمان. }
\end{aligned}
$$

9. لسان العرب، محمد بن مكرم بن على، أبو الفضل، جمال الدين ابن منظور الناشر :

$$
\text { دار صادر - بيروت. }
$$

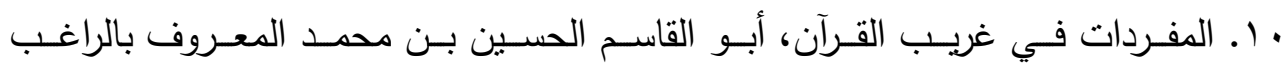

$$
\text { الأصفهانى، المحقق: صفوان عدنان الداودي الناشر: دار القلم. }
$$

11. الجامع لأحكام القرآن تفسير القرطبي، أبو عبد الهه محمد بن أحمد بن أبي بكر بن فرح القرطبي ،تحقيق: أحمد البردوني وإبراهيم أطفيش، دار الكتب المصرية - القاهرة

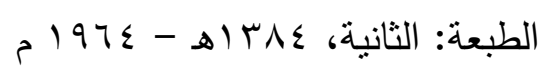

rttp://www.alukah.net ، با. ـ موقع الألوكه على الشبكة العنكبوتية 